\title{
Fotovoltaik dağıtık üretim birimleri (FV-DÜB): güç kalitesine etkileri, uluslararası güç kalitesi standartları ve FV-DÜB barındıran dağıtım sistemleri için güç kalitesi iyileştirme yöntemleri
}

\author{
Alp KARADENi̇ ${ }^{1,2^{*}}$, Murat Erhan BALCI ${ }^{1,2}$ \\ ${ }^{1}$ Balıkesir Üniversitesi Mühendislik Fakültesi, Elektrik-Elektronik Mühendisliği Bölümü, Çă̆lş kampüsü, \\ Balıkesir \\ ${ }^{2}$ Balıkesir Üniversitesi Yenilenebilir Enerji Arş. Uyg. Merkezi, Çă̆ış kampüsü, Balıkesir
}

Geliş Tarihi (Received Date): 22.10.2018

Kabul Tarihi (Accepted Date): 20.06.2019

\section{Özet}

Günümüz güç sistemlerinde gerilim profilinin iyileştirilmesi, sistem güvenilirliğinin arttırılması, hat kayıplarının azaltılması ve enerji verimliliğinin arttırılması amaçlarıyla dağıtık üretim birimlerinin kullanımı yaygın hale gelmiştir. Bu dağıtık üretim birimlerinden, rüzgar türbinleri ve fotovoltaik birimler, elektrik üretiminde doğal gaz, kömür ve petrol gibi geleneksel enerji kaynaklarının kullanımını sınırlandırmaları, böylece sera gazı artışl ve küresel ısınma gibi çevresel sorunların önlenmesi için önemli birer seçenek haline gelmişlerdir. Ancak, bu dağıtık üretim birimleri, güç elektroniği devreleri üzerinden şebekeye bağlanmaları ve enerji kaynaklarının emre amade olmamasl gibi sebeplerden dolayl; güç sistemlerinde çeşitli güç kalitesi problemlerine yol açmaktadır. Bu çalışmada, öncelikle fotovoltaik dağıtık üretim birimlerinde (FV$D \ddot{B B}$ ) teknolojik anlamda gelinen en son durum sunulmuş, daha sonra bu birimlerin güç sistemlerinde meydana getirdikleri güç kalitesi problemleri ile FV-DÜB'leri barındıran sistemler için hazırlanmış uluslararası güç kalitesi standartları irdelenmiştir. Son olarak, FV-DÜB barındıran sistemler için güç kalitesi problemlerinin iyileştirilmesinde uygulanan yöntemler tanıtılmıştır.

Anahtar kelimeler: Fotovoltaik enerji, dağıtık üretim, güç kalitesi.

\footnotetext{
*Alp KARADENIZ, akaradeniz@balikesir.edu.tr, http://orcid.org/0000-0002-0899-6581 Murat Erhan BALCI, mbalci@balikesir.edu.tr, http://orcid.org/0000-0001-8418-8917
} 


\title{
Photovoltaic distributed generation units (PV-DGU): impacts on power quality, international power quality standards and power quality improvement methods for the systems with PV-DGU
}

\begin{abstract}
In today's power systems, the use of distributed generation units has become widespread in order to improve the voltage profile, increase system reliability, reduce line losses and increase energy efficiency. Among these distributed generation units, wind turbines and photovoltaic units have limited the use of traditional energy sources such as natural gas, coal and oil in electricity generation, thus they became important options for the prevention of environmental problems such as greenhouse gas emissions and global warming. However, these distributed generation units are connected to the grid via power electronics circuits and their energy sources are non-dispatchable. Thus, they lead to various power quality problems in the power systems. In this study, firstly, the latest technological case of the photovoltaic distributed generation units (PV$D G U s)$ is presented. Secondly, the power quality problems caused by PV-DGUs in the power systems and the international power quality standards related with the systems containing PV-DGUs are investigated. Finally, the power quality mitigation methods have been detailed for the systems with PV-DGUs.
\end{abstract}

Keywords: Photovoltaic energy, distributed generation, power quality.

\section{Giriş}

Fotovoltaik (FV) hücreler, rüzgar türbinleri, biyokütle, küçük hidro ve yakıt hücreleri temelli elektrik üreten dağıtık üretim birimleri (DÜB), gerilim profilinin iyileştirilmesi, sistem güvenilirliğinin arttırılması, hat kayıplarının azaltılması ve enerji verimliliğinin arttırılması bakımından avantajlar sağladığından, günümüz dağıtım sistemlerinde yaygın şekilde yer almaktadır [1,2]. Ayrıca, bu yenilenebilir enerji temelli DÜB'lerin güç sistemlerinde yaygınlaşması, doğal gaz ve petrol gibi geleneksel enerji kaynaklarının kullanımına bağlı küresel ısınma ve iklim değişikliği sorunlarını engellemek bakımından önemlidir. Yenilenebilir enerji temelli DÜB'lere dayalı elektrik üretimi, geleneksel fosil enerji kaynaklarının yetersizliğinden dolayı meydana gelebilecek enerji krizlerini önlemek için de bir tedbirdir. Bu teknik avantajların yanı sıra, yenilenebilir enerji teknolojisi, fosil yakıt temelli teknolojilere kıyasla daha fazla gelişime açık olduğu için yenilenebilir enerji endüstrisi, yeni istihdam alanları oluşturma bakımından avantajlıdır [3].

FV elektrik üretim birimleri günümüz dağıtım şebekelerinde en hılı şekilde yaygınlaşan yenilenebilir enerji temelli DÜB'lerden birisidir [4]. 2012-2017 y1lları aras1 Dünya çapında yaklaşık olarak $300 \mathrm{GW}$ güç kapasitesinde FV-DÜB kurulmuştur. Böylece 2017 yılında Dünya çapında kurulu FV-DÜB'lerin güç kapasitesi 400 GW'a çıkmıştır. FV-DÜB'lerin kapasitesinde son yıllarda meydana gelen bu artışın sebepleri, FV hücrelerin fiyatlarındaki düşüş, büyük güç seviyeleri için FV sistem elemanlarının imalatındaki teknolojik gelişmeler, hükümet teşvikleri ve ilgili bağlantı yönetmelikleri/standartlarının olgunlaşması gibi çeşitli faktörlerdir [5-7]. 
FV-DÜB'lerin buraya kadar kısaca özetlenen avantajlarına rağmen, boyutlandırılmaları ve şebekeye yerleştirilmeleri doğru yapılmadığı takdirde; elektrik güç sistemlerinde gerilim dalgalanmaları, harmonik bozulma, dengesizlik ve ters güç akışına bağlı hat kayıplarındaki artışlar ile güç sistemlerinde koruma problemleri gibi çeşitli olumsuz etkileri meydana gelir. FV-DÜB'lerin şebekeye düşük güçlerde ve az sayıda nüfuz ettiği geçmiş yıllarda, bu olumsuz etkiler ihmal edilebilir seviyelerdeydi. Ancak, günümüzde bu durum değişmiş; dolayısıyla bahsedilen olumsuz etkilerin önlenmesi için birçok uluslararası standart tarafindan FV-DÜB'lerin uyması gerekli olan şebekeye bağlantı kriterleri tanımlanmıştır $[7,8]$.

Bu çalışmada, öncelikle FV-DÜB'ler için günümüzde teknolojik anlamada gelinen son durum sunulmuş, daha sonra bu birimlerin güç sistemlerinde meydana getirdikleri güç kalitesi problemleri ile FV-DÜB'leri barındıran sistemler için hazırlanmış uluslararası güç kalitesi standartları irdelenmiştir. Son olarak, FV-DÜB barındıran sistemler için güç kalitesi problemlerinin iyileştirilmesinde uygulanan yöntemler tanıtılmıştır.

\section{FV-DÜB teknolojisi}

FV elektrik üretim birimleri, şebekeye bağlı olmayan ve şebekeye bağlı olan şeklinde iki ana sınıfa ayrılırlar. Şebekeye bağlı olmayanlar, elektrik dağıtım sisteminin ulaşmadığı yerlerdeki tüketicilerin beslenmesi için tek başına veya diğer enerji kaynaklarıyla (rüzgar türbinleri, dizel generatörler ve yakıt pilleri gibi) birlikte kullanılan sistemlerdir. Şebekeye bağlı olanlar ise ürettikleri enerjiyi elektrik dağıtım şebekelerine verebilen sistemlerdir [8]. Avrupa'da kurulu olan FV elektrik üretim birimlerinin yaklaşı \% \%98.7'si şebeke bağlı tipte ve \%1.3'ü ise şebekeye bağlı olmayan tiptedir [9].

Tipik bir FV-DÜB'ün yapısı Şekil 1'de verilmiştir. Bu yapıda, FV paneller, d.a.-d.a. dönüştürücü, evirici (d.a.-a.a. dönüştürücü), filtreler ve bağlantı transfornatörü bulunur. FV panellerin çıkışındaki d.a. gerilimin evirici giriş gerilim seviyesine ayarlanması amacıyla opsiyonel olarak; d.a.-d.a. dönüştürücü kullanılmaktadır. d.a.-d.a. dönüştürücü çıkışındaki d.a. elektrik enerjisinin a.a. elektrik enerjisine dönüştürülmesi ise eviricilerle gerçekleştirilmektedir. Bu yapıda ayrıca, evirici çıkışındaki bozuk gerilim dalga şeklinin düzeltilmesi için pasif filtre, şebekeye senkronizasyon ve gerilim-akım-güç gibi çeşitli parametrelerin ölçümü için şebeke izleme birimi ve evirici çıkışındaki gerilimi şebeke gerilimine yükseltecek bir transformatör bulunur. Transformatörün sistemde bulunup bulunmayacağı, şebeke gerilim seviyesine, evirici topolojisine ve evirici kontrol yöntemine bağlıdır [10]. 


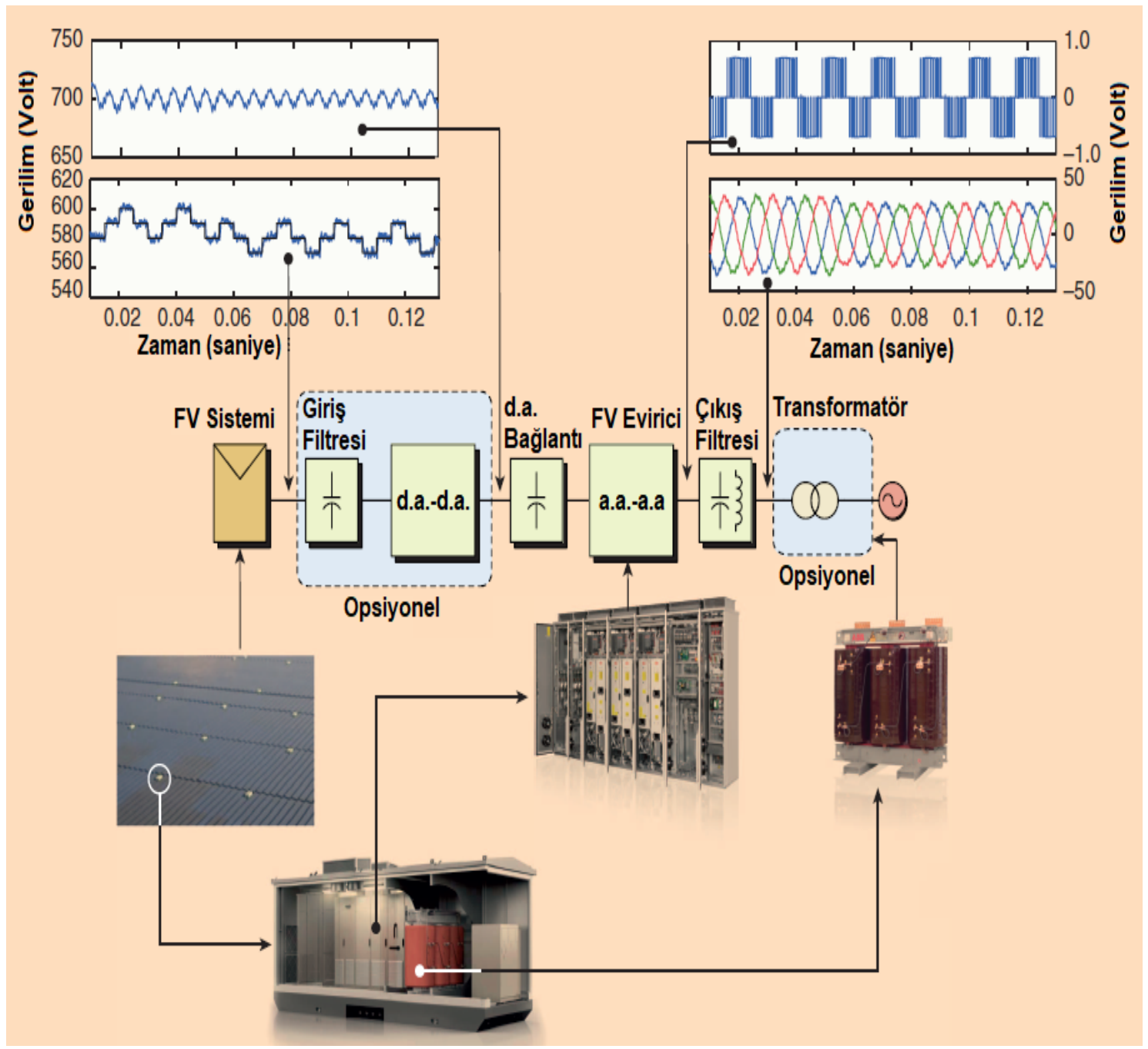

Şekil 1. Tipik bir FV-DÜB'ün yapısı [10].

Şebekeye bağlı FV-DÜB'ler güçlerine göre büyük kapasiteli (FV enerji santralleri: 110MW güçlerde), orta kapasiteli (10-1000 kW güçlerde) ve küçük kapasiteli (10 kW'a kadar güçlerde) FV sistemler olmak üzere üçe ayrılırlar [4]. Büyük ve küçük kapasiteli FV-DÜB'lere ait bağlantı şemaları Şekil 2'de verilmiştir.

Büyük kapasiteli FV-DÜB'ler üç fazlı sistemlerdir ve tipik olarak bir veya daha fazla dağıtım transformatörü üzerinden şebekeye bağlanırlar. Bu sistemler ayrıca çok sayıda birbirine paralel bağlı evirici modüllerine sahiptirler. Orta ölçeklilerin şebekeye bağlantı şekli güçlerine bağlidır. Yüzlerce $\mathrm{kW}$ gücündeki orta ölçekli FV-DÜB'ler büyük ölçekliler gibi ayrı bir dağıtım transformatörü üzerinden şebekeye bağlanırlar. Diğer taraftan, düşük güçlü orta ölçekli FV-DÜB'ler tüketiciye ait küçük güçlü bir transformatör üzerinden şebekeye bağlanabilir. Bununla birlikte şu belirtilmelidir ki küçük kapasiteli FV-DÜB'ler tipik olarak herhangi bir bağlantı transformatörüne ihtiyaç duymazlar ve tek fazlıdırlar [4]. 


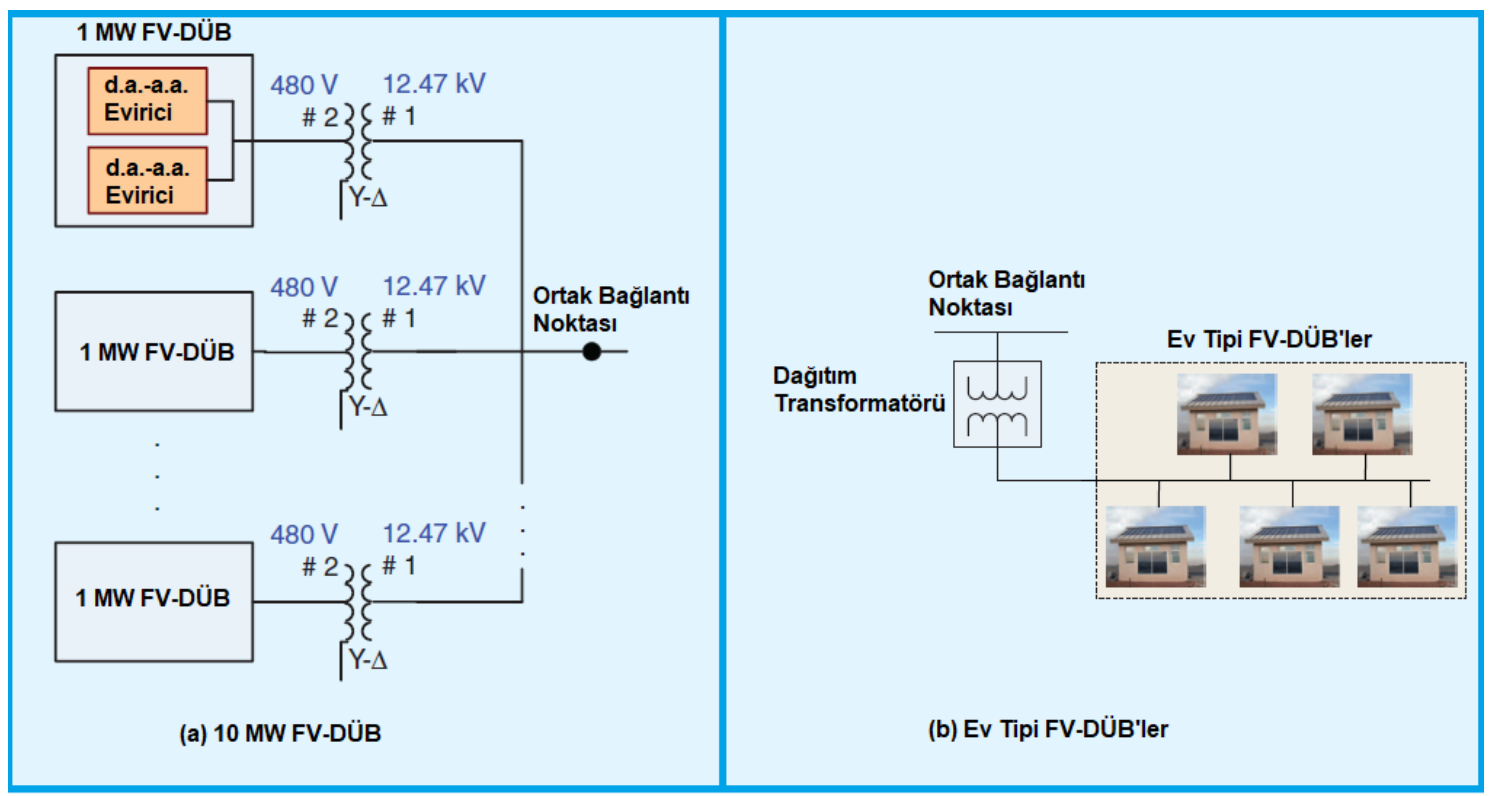

Şekil 2. (a) Büyük ve (b) küçük güçlü FV-DÜB'ler [4].

\subsection{FV evirici băglantı konfigürasyonları}

Şebekeye bağlı FV-DÜB'ler evirici bağlantı konfigürasyonlarına göre; modül eviricili, dizi eviricili, çoklu dizi eviricili ve merkezi eviricili olmak üzere dört farklı tipte sınıflandırılabilir $[9,11,12]$. Bu konfigürasyonların şematikleri Şekil 3'de sunulmuştur.

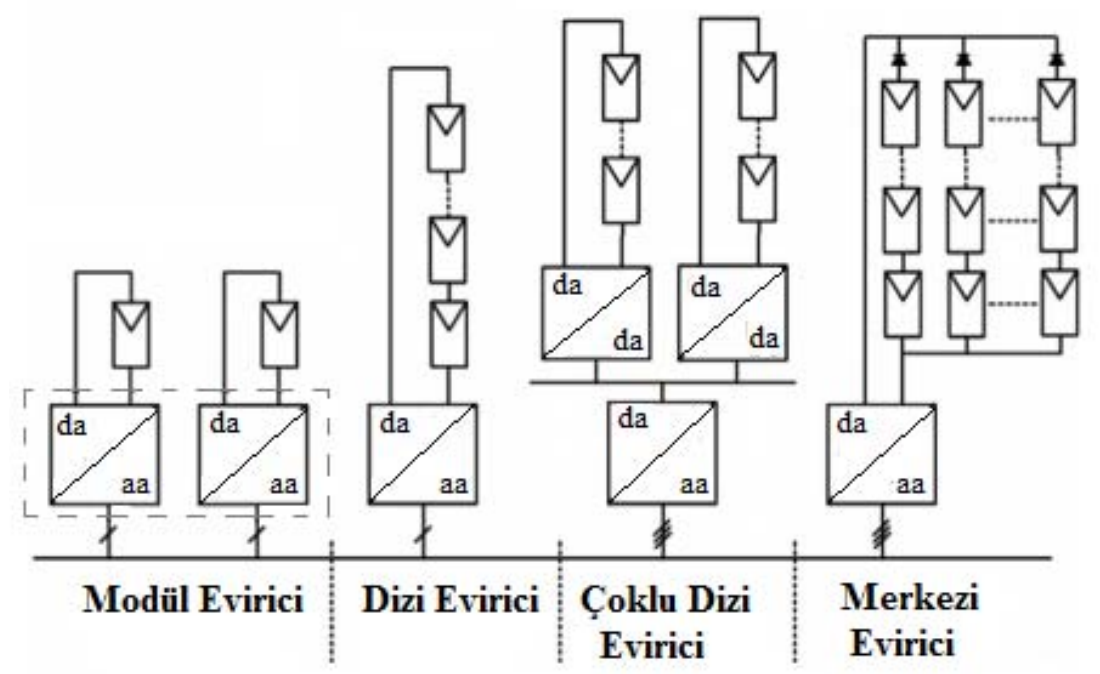

Şekil 3. Evirici konfigürasyonları.

Merkezi eviricili konfigürasyonda, istenilen gerilim ve güç seviyesine ulaşmak için gerekli çok sayıda FV modül evirici üzerinden şebekeye bağlanır. 10-250 kW güç aralığında değişen güç değerlerinde tasarlanabilen bu konfigürasyon santrallerde kullanılmaktadır. Diğer taraftan, merkezi eviricili konfigürasyonun bazı önemli dezavantajları vardır. Bunlar; evirici ile modüller arası bağlantı için yüksek gerilim d.a. kablolarının gerekli olması, merkezi azami güç noktası takip (AGNT) sistemi kaynaklı kayıplar, FV modülleri arası uyumsuzluk kaynaklı kayıplar ve FV dizilerinde bulunan diyotlarda meydana gelen kayıplardır. Dizi eviricili konfigürasyon, merkezi eviricili 
konfigürasyonun küçültülmüş halidir. Bu konfigürasyonda, seri bağlı bir dizi FV modül eviriciye bağlıdır ve bu eviriciler 1 ile $8 \mathrm{~kW}$ arası güç değerlerinde üretilmektedir. Dizi eviricili konfigürasyonda, diyot kayıpları yoktur ayrıca her dizi için ayrı AGNT sistemi kullanıldığı için verim, merkezi eviricili konfigürasyona göre daha yüksektir. Çoklu dizi eviricili konfigürasyonda, her bir FV modül dizisi kendi d.a.-d.a. dönüştürücüsü üzerinden ortak eviriciye bağlanır. Bu konfigürasyonda, her bir dizinin AGNT sistemi ayrıdır; böylece her dizi ayrı ayrı kontrol edilebilir durumdadır. Çoklu dizi evirici konfigürasyon, dizi ve merkezi eviricili konfigürasyonların avantajlarına sahiptir; kompakt ve maliyet açısından verimlidir, 8 ile $20 \mathrm{~kW}$ aralığında güç değerleri için uygulanmaktadır. Modül eviricili konfigürasyonda, sadece bir FV modül ile bir evirici bağlıdır. Böylece, FV modüller arası uyumsuzluk gibi bir sorunla karşılaşılmaz ayrıca FV modül ile evirici arasında optimal çalışma durumu sağlanmış olur. Modül eviricili konfigürasyon günümüzde 150 ile $600 \mathrm{~W}$ güç aralığında üretilmektedir, ancak modül sayısı arttırılarak pratik şekilde güç değeri yükseltilebilir. Diğer taraftan, tek bir FV modülün eviriciye bağlı olması, gerilimin yükseltilmesi ihtiyacını doğurmaktadır. Dolayısıyla, bu konfigürasyonda evirici d.a.-d.a. dönüştürme devresi içermek zorundadır. Modül eviricili konfigürasyonun, aynı güç değeri için diğer konfigürasyonlara kıyasla çok yüksek fiyatlarda olması, bu konfigürasyonun dezavantajıdır. $\mathrm{Bu}$ dört farklı konfigürasyon, verim ve performans bakımından karşılaştırıldığında kötüden iyiye; merkezi evirici, çoklu dizi evirici, dizi evirici ve modül evirici konfigürasyonları olarak sıralanabilir $[9,11,12]$.

\subsection{FV hücresinin eşdeğer devre modeli ve azami güç noktası takibi}

$\mathrm{Bu}$ kısımda sırasıyla, FV hücresinin modellenmesi ve azami güç noktası takibi üzerine literatür sunulacaktır:

\subsubsection{FV hücresinin eşdeğer devre modeli}

FV hücresinin ideal eşdeğer devresi ve I-V karakteristiği sırasıyla, Şekil 4 (a) ve (b)'de verilmiştir. $\mathrm{Bu}$ ideal eşdeğer devrede, IPV Güneş 1şı ğının hücre üzerine düşmesi neticesinde üretilen elektrik akımını, $I$ hücrenin çıkış akımını ve $V$ hücrenin çıkış gerilimini ifade etmektedir.

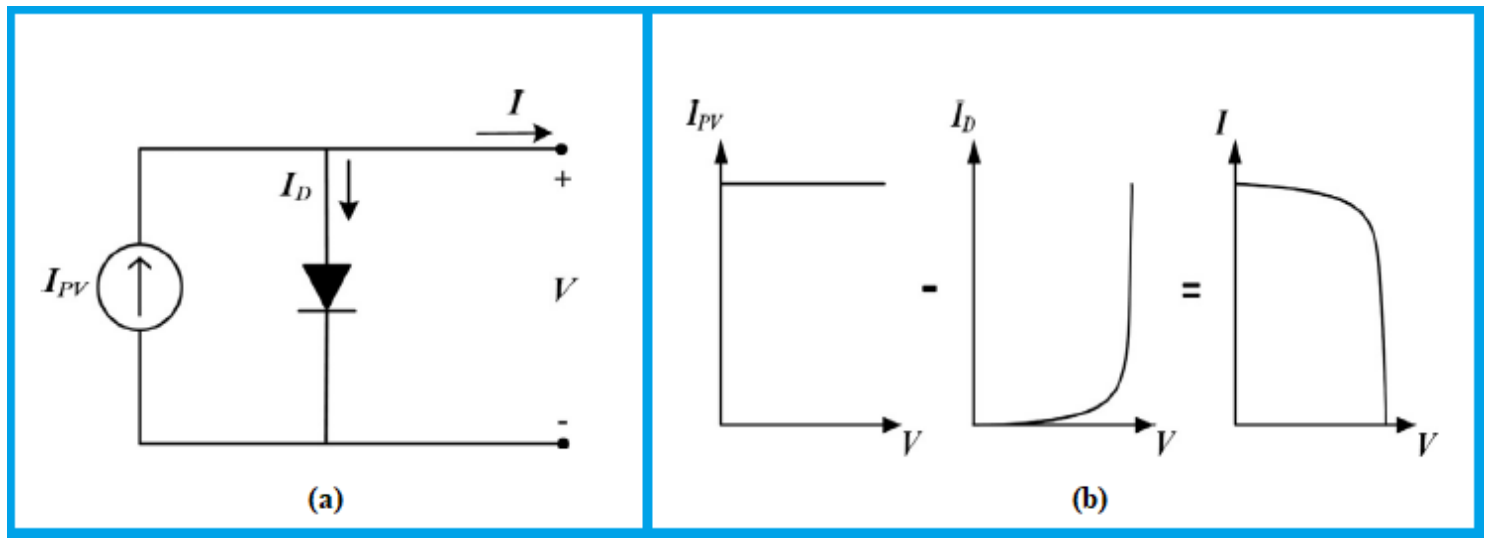

Şekil 4. FV hücresinin (a) ideal eşdeğer devresi ve (b) I-V karakteristiği [13].

FV hücresi, üzerine Güneş 1şı̆̆ 1 düşmediği durumda basit bir diyot gibi davranır. Bu sebeple, eşdeğer devrede akım kaynağına paralel bağlı bir diyot bulunur, bu diyotun 
çektiği akım eşdeğer devre üzerinde $I_{\mathrm{D}}$ ile ifade edilmiştir. ID akımı, diyotun doyum akımı $\left(I_{0}\right)$ ve kalite faktörü $(a)$, elektron yükünün mutlak değeri $\left(q=1.602176 \times 10^{-19} \mathrm{C}\right)$, Boltzmann sabiti $\left(k=1.380653 \times 10^{-23} \mathrm{~J} / \mathrm{K}\right)$ ve yar1 iletken eklemin Kelvin birimi cinsinden sıcaklığı $(T)$ ve diyot gerilimi $(V)$ dikkate alınarak Denklem (1)'de verilen biçimde yazılabilir:

$I_{D}=I_{0}\left[e^{\left(\frac{q V}{a k T}\right)}-1\right]$

Böylece, eşdeğer devrede Kirchoff akımlar kanunu uygulanarak hücrenin çıkış akımı,

$$
I=I_{P V}-I_{D}=I_{P V}-I_{0}\left[e^{\left(\frac{q V}{a k T}\right)}-1\right]
$$

ifadesiyle hesaplanabilir.

$\mathrm{Bu}$ eşdeğer devreye göre, hücre üzerine düşen Güneş 1şığının sabit olduğu durum için $I_{\mathrm{PV}}, I_{\mathrm{D}}$ ve $I$ akımlarının $V$ ile değişimleri Şekil 4 (b)'de gösterildiği biçimde elde edilir. $\mathrm{Bu}$ şekilde verilen I-V eğrisi, FV hücresinin akım-gerilim karakteristiği olarak literatürde isimlendirilmiştir [13]. Bu şekilden görüldüğü üzere, FV hücreleri doğrusal olmayan I-V karakteristiğine sahiptir.

Diğer taraftan, kayıpların seri ve paralel direnç olarak sembolize edildiği ve literatürde yaygın olarak bilinen FV hücresinin gerçekçi eşdeğer devresinin şematiği ise Şekil 5'de sunulmuştur. $\mathrm{Bu}$ eşdeğer devrede, $R_{\mathrm{S}}$ direnci hücre içindeki yarı iletken malzemenin, elektrotların ve yarı iletken malzeme - elektrotlar arası temas noktası dirençlerinin toplamıdır. $R_{\mathrm{P}}$ direnci ise yarı iletken malzeme içindeki kaçak akımlardan dolayı meydana gelen direnç olarak açıklanabilir. Bu gerçekçi seri ve paralel dirençli FV eşdeğer devresine göre; çıkış akımı Denklem (3)'de verilen ifadeyle hesaplanabilir [13]:

$$
I=I_{P V}-I_{0}\left[e^{\left(\frac{q\left(V+I R_{S}\right)}{a k T}\right)}-1\right]-\frac{\left(V+I R_{S}\right)}{R_{P}}
$$

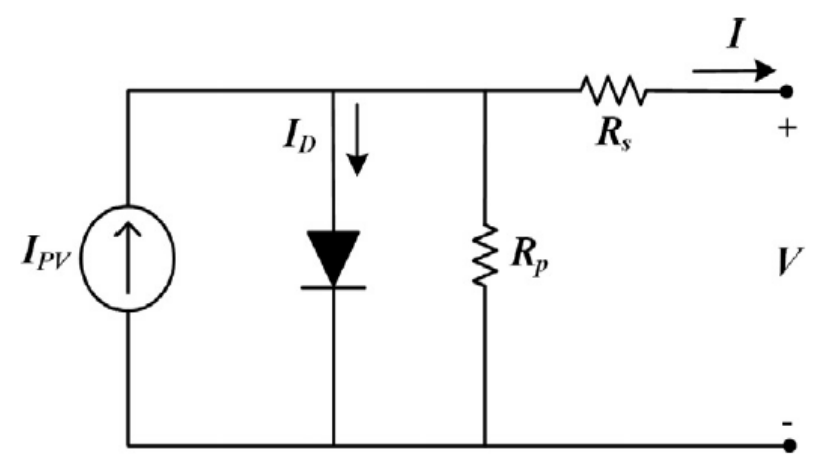

Şekil 5. Seri ve paralel dirençli (gerçekçi) FV eşdeğer devresi [13]. 


\subsubsection{AGNT yöntemleri}

Şekil 6'da sunulan FV panel akımı (I)-FV panel gerilimi (V) ve FV panel gücü (P)- FV panel gerilimi (V) karakteristik eğrileri, FV gerilimi, akımı ve gücünün ortam sıcaklığı ve Güneş ışınımına bağlı olduğunu göstermektedir. Bu karakteristik eğriler üzerinde okla gösterilen noktalar, FV hücrelerinin her bir ortam sıcaklığı-Güneş ışınımı durumu için azami güç noktasını (AGN) göstermektedir. Azami güç noktası takip (AGNT) sistemleri, değişken atmosferik şartlar altında FV hücrelerinden azami güç üretimini sağlayan kontrol devreleridir. Bu devreler AGN'ye karşıllk gelen FV işletme gerilimini hesap eder ve gerilimi bu hesapladığı değerde tutacak biçimde d.a.-d.a. dönüştürücü veya evirici devrelerini kontrol eder. Böylece, FV-DÜB'lerin her türlü koşulda azami çıkış gücü üretmesini sağlar [14].

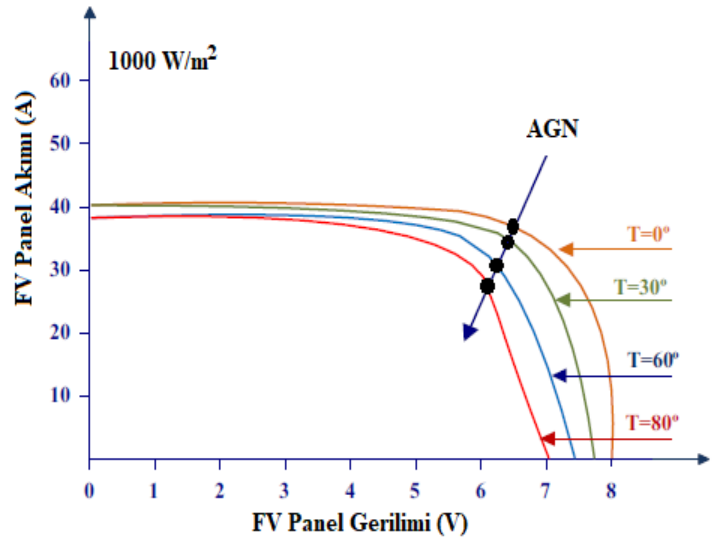

(a)

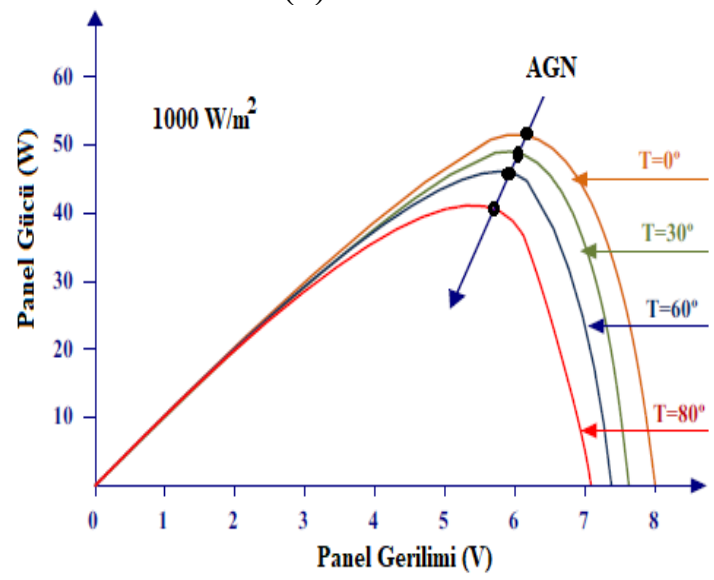

(c)

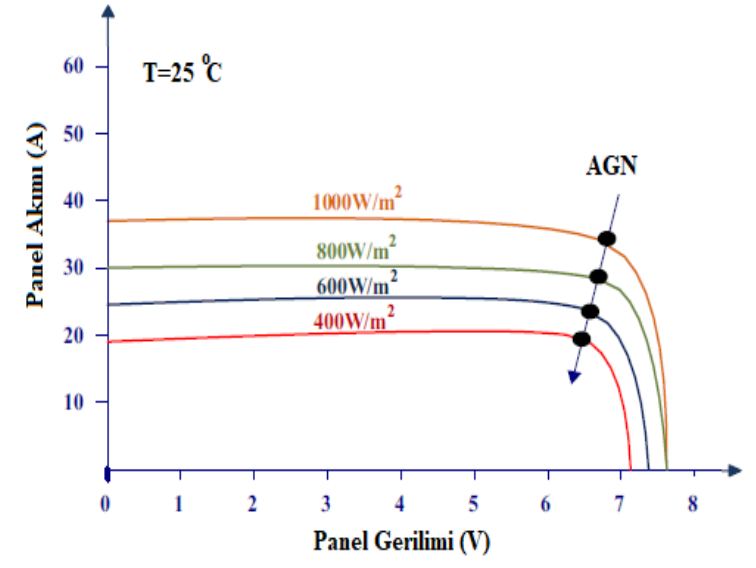

(b)

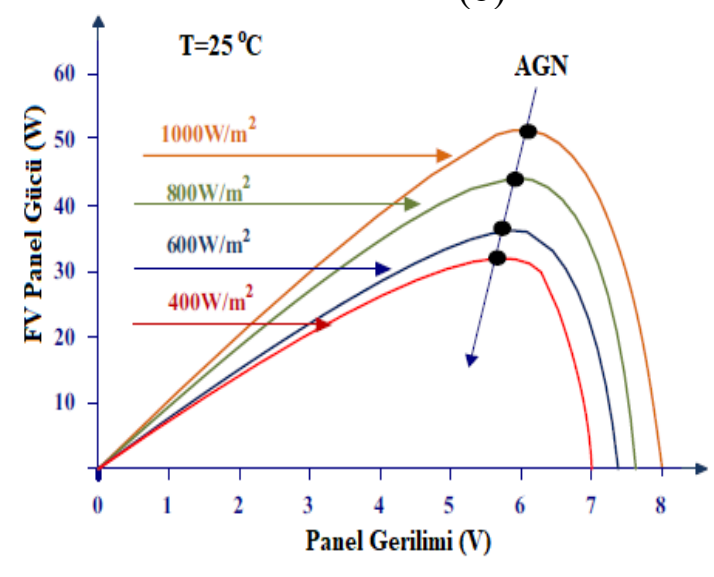

(d)

Şekil 6. FV hücresinin sabit Güneș 1șınımı $\left(\mathrm{P}=1000 \mathrm{~W} / \mathrm{m}^{2}\right)$ ve değişken ortam sıcaklıkları için (a) I-V ve (c) P-V eğrileri, sabit ortam sıcaklığı $\left(T=25^{\circ} \mathrm{C}\right)$ ve değişken Güneş 1şınımları için (b) I-V ve (d) P-V eğrileri [14].

Literatürde, AGNT için çok sayıda çevrim içi, çevrim dışı ve akıllı yöntemler önerilmiştir. Ancak, bu yöntemler arasında, yaygın olarak bilinenler; Karıştır-Gözlemle (KG), Artımlı İletkenlik (Aİ), Açık Devre Gerilimi (ADG) ve Kısa Devre Akımı (KDA) temelli kontrol yöntemleri olup ticari ürünlerde uygulama kolaylığı sebebiyle KG yöntemi yaygın olarak kabul görmüştür [14]. KG yöntemi, adım adım gerçekleştirilen gerilim değişimleriyle birlikte FV dizisinin çıkış gücünde meydana gelen değişimlerin değerlendirilmesine dayanır $[14,15]$. Bu yöntemde öncelikle, FV dizisinin çıkış 
geriliminin ve akımının ölçülen değerleri, kullanılarak FV dizisinin gücü hesap edilir. Daha sonra, FV dizisinin gerilimi küçük bir değerde $(\Delta V)$ değiştirilir ve devamında FV dizisinin çıkış gücünde meydana gelen değişim $(\Delta \mathrm{P})$ ölçülür. Eğer $\Delta \mathrm{P}$ ve $\Delta \mathrm{V}^{\prime}$ nin her ikisi de pozitif veya negatif değerlerde ise; FV çıkış geriliminin, P-V eğrisi üzerinde AGN'nin sol tarafinda kalan noktalara denk düştüğü tespit edilir. $\mathrm{Bu}$ durumda, $\Delta \mathrm{V}^{\prime}$ 'nin işaretinin pozitif veya negatif olması; sırasıyla AGN'ye yaklaşıldığı veya AGN'den uzaklaşıldığı manasına gelir. Eğer $\Delta \mathrm{P}$ veya $\Delta \mathrm{V}$ 'nin birinin işareti negatif ise; $\mathrm{FV}$ çıkış geriliminin, $\mathrm{P}-\mathrm{V}$ eğrisi üzerinde AGN'nin sağ tarafında kalan noktalara denk düştüğü tespit edilir. $\mathrm{Bu}$ durumda, $\Delta \mathrm{V}^{\prime}$ 'nin işaretinin pozitif veya negatif olması; sırasıyla AGN'den uzaklaşıldığı veya AGN'ye yaklaşıldığı manasına gelir. $\Delta \mathrm{P}$ sıfır olduğu durum AGN'ye karşılık gelen çalışma durumudur. Bu algoritmanın diğer yöntemlere göre dezavantajları; adım aralığı küçük seçildiğinde daha yavaş cevap vermesi ve adım aralığı yüksek seçildiğinde ise AGN etrafinda dalgalanmalara dolayısıyla verim düşüşüne yol açmasıdır.

Şekil 7'den görüldüğü üzere P-V eğrisinin eğimi $(\mathrm{dP} / \mathrm{dV})$, eğrinin sol tarafinda pozitif, eğrinin sağ tarafinda negatif ve tepe noktasında (AGN'de) sıfırdır. Aİ algoritması, P-V eğrisinin eğimine $(\mathrm{dP} / \mathrm{dV})$ göre $\mathrm{AGN}$ tespiti yapan bir algoritmadır $[14,15]$.

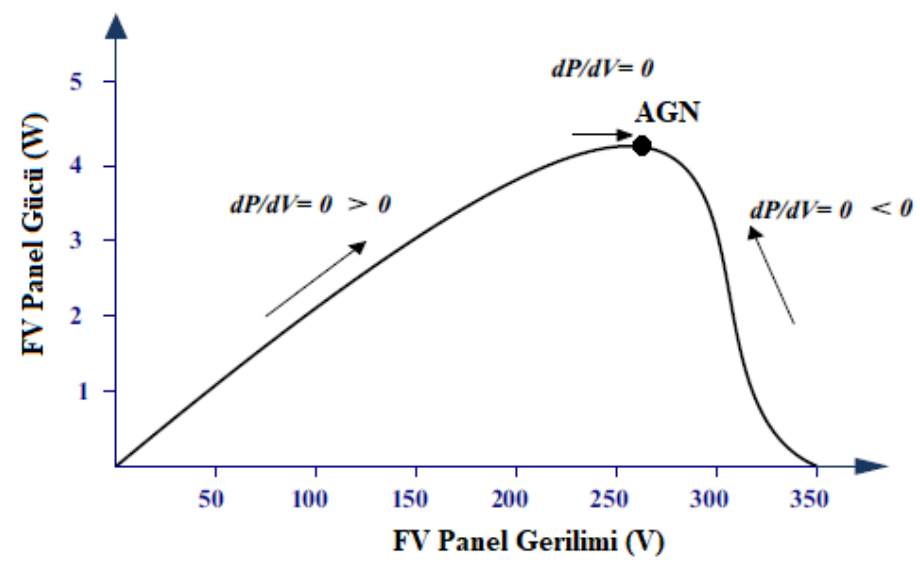

Şekil 7. FV hücreye ait P-V eğrisinin eğimi [14].

$\mathrm{Bu}$ yöntemin uygulanmasında FV dizisinin çıkış gerilimi ve akımı belli zaman aralıklarıyla ölçülür. Her bir ölçüm çifti ve bir önceki çifti dikkate alınarak, FV dizisinin iletkenliği I/V ve artımlı iletkenliği $(\mathrm{dI} / \mathrm{dV}=\Delta \mathrm{I} / \Delta \mathrm{V})$ hesaplanır. Böylece, Denklem (4)'de verilen arama kriterine göre, Şekil 7'de verilen P-V eğrisi üzerinde AGN'nin hangi tarafında arama yapıldığı tespit edilir. Aİ algoritmasının, KG algoritmasına göre AGN civarında daha az dalgalanmaya yol açması literatürdeki çalışmalarda belirtilmiştir. Diğer taraftan, Aİ algoritmasının daha karmaşık kontrol devresi gerektirmesi maliyet bakımından dezavantajıdır.

$$
\text { Aİ arama kriteri }=\left\{\begin{array}{lr}
\frac{d I}{d V}=-\frac{I}{V} \Rightarrow \frac{d P}{d V}=0 & \text { AGN noktasında çalışılıyor } \\
\frac{d I}{d V}>-\frac{I}{V} \Rightarrow \frac{d P}{d V}>0 & \mathrm{P}-\mathrm{V} \text { eğrisinin sol tarafında çalışılıyor } \\
\frac{d I}{d V}<-\frac{I}{V} \Rightarrow \frac{d P}{d V}<0 & \mathrm{P}-\mathrm{V} \text { eğrisinin sağ tarafinda çalışılıyor }
\end{array}\right\}
$$


ADG yönteminde, açık devre gerilimi ( $\mathrm{VAD}$ ) ve AGN için gerekli olan gerilim (VAGN) arasında var olan, Denklem (5)'de ifade edilen doğrusal ilişki dikkate alınır [14, 15]. Bu ilişkide, Kv katsayısı (gerilim faktörü), FV hücrenin karakteristiğine, ortam sıcaklığına ve Güneş ışınımına göre farklı değerler alır.

$V_{A G N}=K_{V} V_{A D}$

ADG yönteminin uygulanmasında, FV diziler ile güç dönüştürücü arasına seri olarak bir statik anahtar bağlanır. $\mathrm{Bu}$ anahtar belli zaman aralıklarla açılıp kapatılarak FV çıkışından dönüştürücüye akan akım sıfır yapılır ve böylece FV dizisinin çıkışındaki $\mathrm{V}_{\mathrm{AD}}$ ölçülür. Böylece Denklem (5)'den $\mathrm{V}_{\mathrm{AGN}}$ hesap edilerek AGNT işlemi gerçekleştirilir. Bu algoritma ölçülen parametre sayısının azlığı ve türev alma işlemine ihtiyaç duymaması sebebiyle KG ve Aİ yöntemlerine göre daha hızlıdır. Bununla birlikte, yöntemin en büyük dezavantajı açık devre geriliminin örneklenmesi için yapılan anahtarlama işlemi sırasında meydana gelen kayıplardır [14].

KDA yönteminde, kısa devre akımı (IKD) ve AGN durumunda ölçülen FV çıkış akımı (IAGN) arasında var olan, Denklem (6)'da ifade edilen doğrusal ilişki dikkate alınır [14, 15]. $\mathrm{Bu}$ ilişkide, $\mathrm{K}_{\mathrm{I}}$ katsayısı (akım faktörü) FV hücresinin karakteristiğine, ortam sıcaklığına ve Güneş ışınımına göre farklı değerler alır.

$$
I_{A G N}=K_{I} I_{K D}
$$

KDA yönteminin uygulanmasında, FV diziler ile güç dönüştürücü arasına paralel olarak bir statik anahtar bağlanır. Bu anahtar belli zaman aralıklarla açılıp kapatılarak FV çıkışı kısa devre edilir ve FV dizisinin IKD akımı ölçülür. Böylece Denklem 6' dan IAGN hesap edilerek AGNT işlemi gerçekleştirilir. ADG ve KDA yöntemlerinin çalışma prensiplerinin benzer olması sebebiyle, bu yöntemlerin diğer iki yönteme ( $K G$ ve Aİ) göre avantajları ve dezavantajları aynıdır [14].

\subsection{FV-DÜB'ler için evirici topolojileri}

Modül, dizi, çoklu dizi ve merkezi FV evirici konfigürasyonlarında kullanılan ticarileşmiş çeşitli evirici topolojilerinin şematikleri Şekil 8'de verilmiştir [10].

$\mathrm{Bu}$ şekilden, dizi FV konfigürasyonu için transformatör (Tr.) üzerinden şebekeye bağlanan H-köprü, transformatörsüz H-köprü, yüksek frekans transformatörlü (Y.F. Tr.) H-köprü, H5, HERIC, H6D1, H6D2, T-tipi, üç-seviyeli-nötr noktası kilitlemeli (NNK), beş-seviyeli-NNK ve asimetrik kaskad bağlı H-köprü (KBHK) topolojilerinin olduğu görülmektedir. Aynı şekil, çoklu dizi FV konfigürasyonu için H-köprü, üç-seviyeliNNK ve iki-seviyeli- gerilim kaynağı evirici (GKE) topolojilerinin, merkezi FV konfigürasyonu için üç-seviyeli-T-tipi, üç-seviyeli-NNK ve iki-seviyeli-GKE topolojilerinin, modül FV konfigürasyonu için Y.F. Tr.li H-köprü ve sarmaşık yapılı flyback dönüştürücülü H-köprü topolojilerinin kullanıldığını göstermektedir. Burada şu belirtilmelidir ki dizi FV konfigürasyonu için kullanılan bütün topolojiler çoklu dizi konfigürasyonu için de kullanılabilir, bu topolojiler Şekil 8'de ayrıca çoklu dizi FV konfigürasyonu için tekrar sunulmamıştır. 


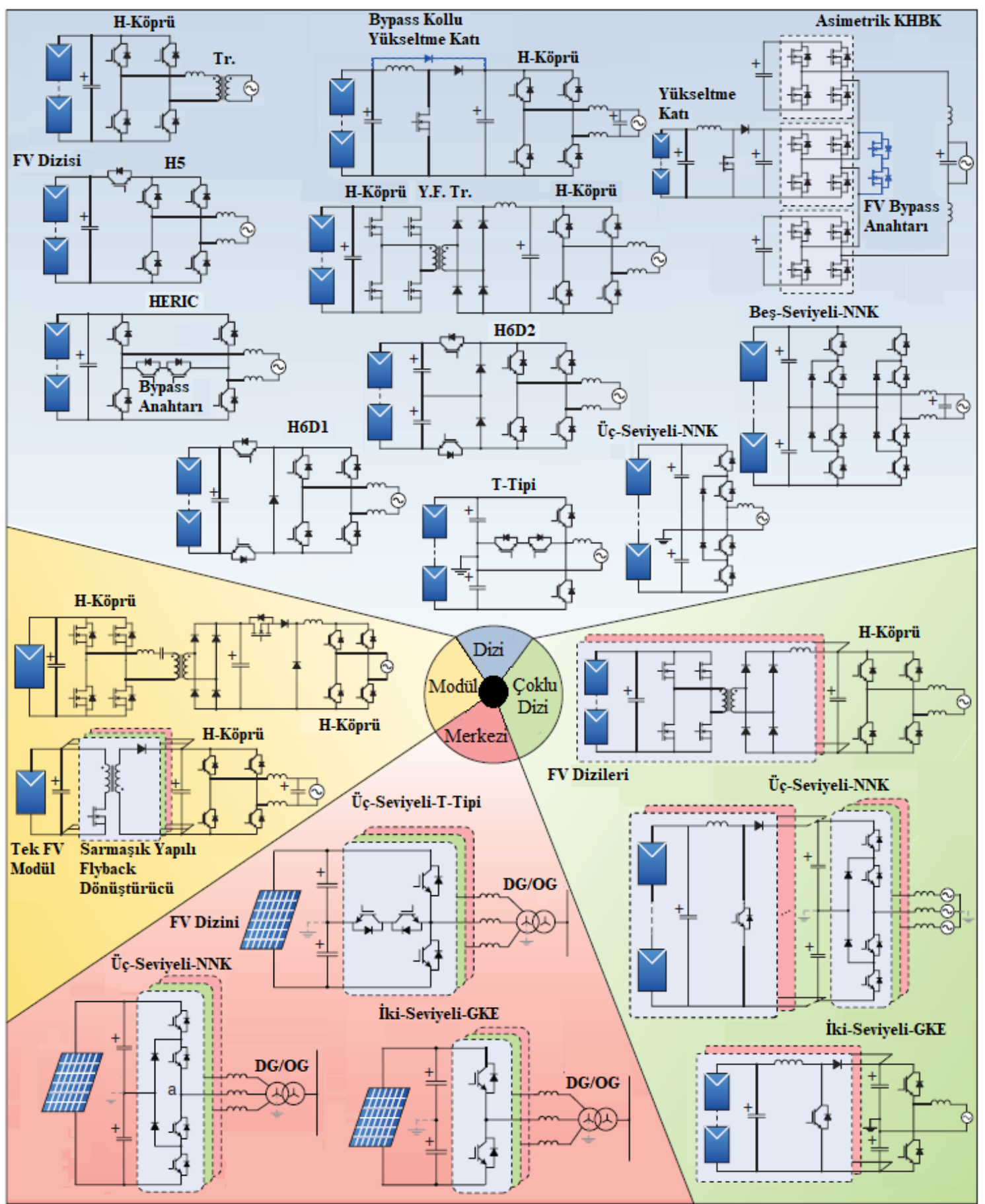

Şekil 8. FV sistemler için evirici topolojileri [10].

Evirici topolojileri incelendiğinde, topolojilerin transformatörlü ve transformatörsüz olmak üzere iki ana başlık altında toplanabileceği görülmektedir. Daha önce belirtildiği gibi, topolojilerdeki şebeke frekansı bağlantı transformatörleri, evirici çıkışındaki gerilimin, şebeke gerilim seviyesine yükseltilmesi görevindedir. Şebeke frekans1 bağlantı transformatörleri, dağıtım transformatörlerinde doymaya sebep olan d.a. akımların şebekeye akışını engeller ve şebeke-FV paneller arası izolasyonu (galvanik izolasyonu) sağlar. Ancak, bu transformatör kullanımı eviricinin boyutunu büyütmekte, maliyeti arttırmakta ve verimi düşürmektedir. $\mathrm{Bu}$ sebeple birçok yeni evirici topolojisinde gerilim yükseltme işlemi, yüksek frekans transformatörleriyle veya d.a.- 
d.a. dönüştürücülerle gerçekleştirilmektedir. Yüksek frekans transformatörlü topolojilerde, FV kaynak çıkışındaki d.a. gerilim, bir H-köprü eviriciyle yüksek frekanslı a.a. gerilime dönüştürülür, bu gerilim seviyesi daha sonra transformatörle yükseltilir ve bir köprü doğrultucuyla doğrultularak şebeke frekansında çıkış veren ikinci H-köprü eviriciye verilir. Yüksek frekanslı transformatörler şebeke-FV kaynak arası galvanik izolasyon sağlamakla birlikte d.a. akımın şebekeye akış problemini ortadan kaldırmaz. Diğer taraftan, transformatörsüz evirici tiplerinde, FV panel ve şebeke arası yüksek kaçak akımları önlemek için; (i) özel modülasyon teknikleriyle ortak mod gerilim ayarı, (ii) bypass anahtarlarının kullanımı ve (iii) d.a. ortak bağlantı noktası ile şebeke nötür noktasının aynı yere topraklanması gibi yöntemler tercih edilmiştir [10].

\section{FV-DÜB'lerin şebekeye olumsuz etkileri ve bağlantı standartları}

Son yıllarda, yenilenebilir enerji temelli dağıtık üretim birimlerinin sayılarında ve kapasitelerinde önemli derecede artış meydana gelmiştir $[5,6]$. Bu dağıtık üretim birimlerinin, geleneksel elektrik üretim birimlerinden farklı olarak; kısmen tahmin edilebilir ve kesintili üretim karakteristiğine sahip olması yanı sıra güç elektroniği devreleri üzerinden şebekeye bağlanmaları sebebiyle güç kalitesi, kararlılık ve güvenilirlik problemlerine yol açmaları söz konusudur. Bu problemleri önlemek amacıyla, ülkelerin ilgili kurumları/kuruluşları ve çeşitli uluslararası organizasyonlar tarafından FV-DÜB'lerin elektrik güç sistemlerine bağlantısı için gereklilikleri tanımlayan birçok standart hazırlanmıştır $[7,11,12]$. Uluslararası düzeydeki standartlardan yaygın olarak tanınan ve kullanılanları; "Dağıtık kaynakların elektrik güç sistemlerine bağlantısı için IEEE standardı" başlıklı IEEE $1547[16,17]$ ve "FV sistemleri-şebeke arabirimi karakteristikleri” başlıklı IEC 61727 [18] standartlarıdır. IEEE 1547 standardı, anma gücü 10 MVA'nın altındaki DÜB'lerin şebekeye bağlantısı için teknik gereklilikleri ve test prosedürlerini ortaya koymuştur. IEC 61727 standardi ise anma gücü $10 \mathrm{kVA}$ altındaki FV-DÜB'lerin alçak gerilim dağıtım sistemlerine bağlantısı üzerine gereklilikleri tanımlayan standarttır. Bir diğer önemli uluslararası standart ise "FV sistemlerin şebekeye bağlantı arabirimleri için tavsiye edilen uygulamalar" başlıklı IEEE 929 standardıdır [19]. Bu standart, dağıtım sistemine bağlı, anma gücü $10 \mathrm{~kW}$ altında olan FV sistemler için bir pratik kılavuz sunmuştur. $\mathrm{Bu}$ kılavuz, can güvenliği, sistem koruma, güç kalitesi ve şebekenin işletilmesiyle alakalı hususları kapsamaktadır.

FV-DÜB'lerin sebep olduğu güç kalitesi problemlerinden önde gelenleri; gerilim dalgalanmaları, gerilim yükselmesi, gerilim dengesizliği ve harmonik bozulma ile d.a. bileşene sahip akımların şebekeye enjekte edilmesi olarak sıralanabilir [8, 20, 21]. Aşağıda, bu güç kalitesi problemleri hakkında bilgi verilip; IEEE 1547, IEC 61727 ve IEEE 929 uluslararası standartlarının bunların önlenmesi için getirdiği sınırlamalar tanitılacaktır.

\subsection{Gerilim dalgalanmaları / gerilim yükselmesi}

FV-DÜB'lere bağlı meydana gelen gerilim dalgalanma probleminin ana sebebi, bulutlanma ve açık hava gibi atmosferik olaylar neticesinde Güneş enerjisinin kesintili karakterde olmasına (Güneş enerjisinin emre amade olmamasına) bağlı olarak, FVDÜB'lerin çıkış gücünde meydana gelen değişimler olarak ifade edilebilir [8, 20, 21]. 
Diğer taraftan, dağıtım sistemlerinde hat kayıplarını minimize etmek ve gerilim profilini iyileştirmek için FV-DÜB'ler tüketicilere yakın noktalara bağlanır ve tüketicilerin güçlerini aşmayacak güç değerlerinde boyutlandırılırlar. Ancak, aksi takdirde, FVDÜB'ler yükleri beslemenin yanı sıra dağıtım hattını da beslerler. Böylece, yük tarafından hatta doğru ters güç akışı meydana gelir ve yük barasındaki gerilim değeri yükselir. Dolayısıyla ters güç akışı, FV-DÜB'lerin bulunduğu sistemlerde gerilim yükselmesi probleminin önde gelen sebeplerindendir [8, 20, 21]. Şekil 9'da verilen şematik ve grafiklerle, güç akış yönünün gerilim seviyesine etkisi gösterilmiştir. Ters güç akışı, dağıtım hattında meydana gelen kısa devre arıza durumunda, arızanın hem şebeke hem de FV-DÜB tarafından beslenmesine yol açar, bu ise arıza akımın değerini büyütür [8].

IEEE 1547 (2003) ve IEC 61727 standartlarında, FV-DÜB'ler için şebeke geriliminin düzenlenmesinde bir sorumluluk tanımlanmamıştır. Ancak, bu üretim birimlerinin şebekeye bağlandığı durumda, sistem gerilimi ilgili sınırları aşmamalıdır. Diğer taraftan, IEEE 1547 (2014) [17] standard1, DÜB'lerin, aktif ve reaktif güç ayarıyla sistem gerilimini düzenleme işlemine desteğini gerekli görmektedir. Aynı standart sistemdeki gerilim dalgalanmasını, anma geriliminin $\% \pm 5$ 'i içinde sınırlandırmaktadır.

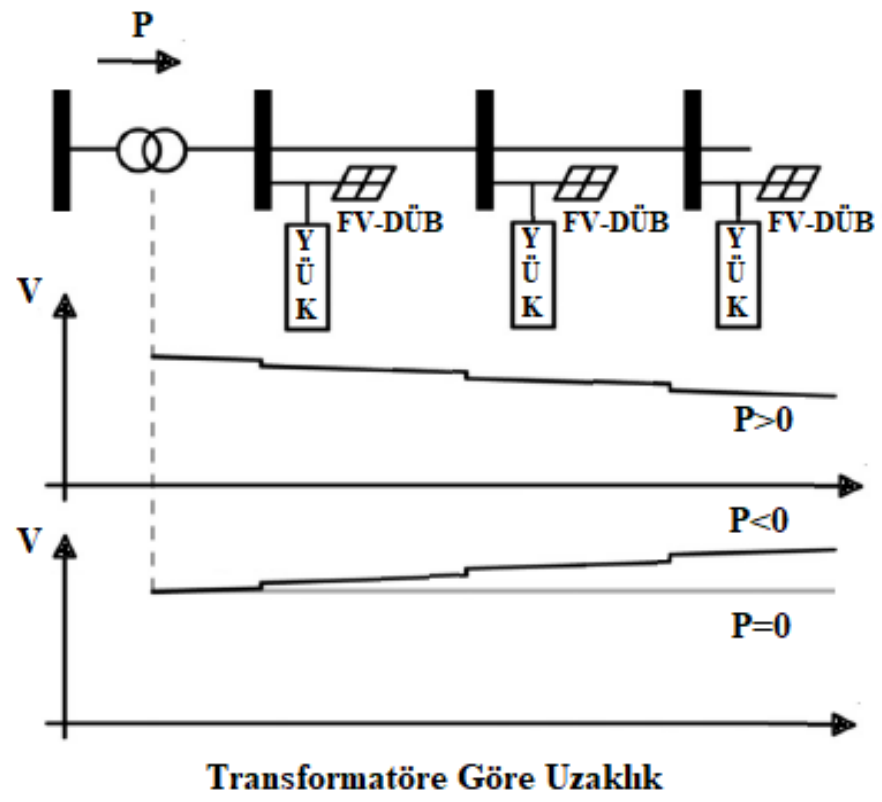

Şekil 9. FV-DÜB’lerin olduğu sistemlerde gerilim dalgalanması [8].

\subsection{Gerilim dengesizliği}

FV-DÜB'lerin güç kalitesine en önemli olumsuz etkilerinden biri gerilim dengesizliğidir. Gerilim dengesizliği, üç faz gerilimlerinin etkin değerlerinin birbirine eşit olmaması ve/veya aralarında 120'şer derece faz farkı olmaması durumudur $[22,23]$. Geleneksel güç sistemlerinde dengesizliğin sebepleri arasında eşit empedansa sahip olmayan hatlar, tek fazlı yüklerin eşit güçlerde fazlara dağıtılmaması ve asimetrik güç sistem arızaları olarak sayılabilir [23], diğer taraftan; günümüz modern güç sistemleri için bu sebeplere, ev tipi tek fazlı FV-DÜB'lerin fazlara eşit güçlerde dağıtılmaması 
eklenmiştir [8, 24]. Dengesizliğin en önemli olumsuz etkilerinden biri asenkron makinalarda aşırı ısınma, ömür kaybı ve tork dalgalanmalarına yol açmasıdır [23].

Üç fazlı FV-DÜB'lerde ise dengesizliğe bağlı olarak çıkış gücünde dalgalanmalar ve çıkış akımının harmonik bozulmasında artış meydana gelmektedir. Literatürdeki birçok çalışmada $[25,26]$, dengesizliğin üç fazlı FV-DÜB'ler üzerindeki bu olumsuz etkilerini minimize etmeyi amaçlayan kontrol algoritmaları önerilmiştir. IEEE 1547 ve IEC 61727 standartları FV-DÜB'lerin çıkış gerilimi dengesizliği için bir sınırlama tanımlamamıştır. Bununla birlikte, uluslararası standartlar genellikle gerilim dengesizlik oranını (negatif sıra ve pozitif sıra gerilim genliklerinin oranını) \%2 ile sınırlandırmıştır [7].

\subsection{Harmonik bozulma ve doğru akım bileşene sahip akımlar}

FV-DÜB'lerin yapısında bulunan evirici devrelerinin, şebekeye enjekte ettiği akımlar sinüzoidal olmayan (harmonik bozulmalı) dalga formuna sahiptir [8, 20]. Gerilim ve akım harmonik bozulması, generatörler, transformatörler, asenkron motorlarda ve kompanzasyon kondansatörlerinde kayıp artışına, aşırı ısınma ve ömür kaybına, asenkron motorlarda güç faktörünün düşmesine ve tork dalgalanmalarına, hat iletkenlerinde kayıp artışlarına, koruma, kontrol ve ölçme sistemlerinin hatalı çalışmasına yol açan önemli bir güç kalitesi problemidir [27, 28].

FV-DÜB'lerin akım harmonik bozulma karakteristiğini analiz eden birçok çalışma literatürde mevcuttur [29-31]. Bu çalışmalardan, FV-DÜB'lerin şebekeye enjekte ettiği harmonik akımlarının temel frekans akımına göre bağıl değerlerinin Güneş ışınımıyla ters orantılı ilişkiye sahip olduğu bir başka ifadeyle düşük Güneş ışınımı değerlerinde daha fazla harmonik bozulmaya yol açtığı görülmektedir. Güç faktörünün ise FVDÜB'lerin akım harmonik bozulmasına önemli bir etkisinin olmadığı [31]'de belirtilmiştir.

FV-DÜB'ler için harmonik sınırlamalar bakımından yaygın olarak dikkate alınan standartlar, IEEE 1547 ve IEC 61727 standartlarıdır [7]. Bu standartların yanı sıra, ortak bağlantı noktası için harmonik sınırlamaları getiren IEEE 519 standardı [32], FVDÜB'lerin harmonik kirlilik seviyesi dikkate alınarak güç sistemlerine entegrasyonu üzerine yapılmış birçok çalışmada [33-35] dikkate alınmıştır. Bu üç standart tanımladıkları harmonik sınırlamalar bakımından karşılaştırıldığında, IEEE 1547 ve IEC 61727 standartlarının birbirine çok yakın olduğu [7], diğer taraftan IEEE 1547 standardının IEEE 519 standardına göre daha sıkı olduğu [35], ifade edilebilir.

Galvanik izolasyona sahip olmayan (transformatörsüz) FV-DÜB'ler yapılarında evirici devreleri olması sebebiyle şebekeye d.a. akım enjekte ederler. d.a. akım şebeke servis sağlayıcıya ait dağıtım transformatörlerinin çekirdeklerinin doymasına yol açar, bu doyma neticesinde transformatörlerin reaktif güç ihtiyacı ve kayıları artar. Kayıp artışına bağlı olarak transformatörler aşırı 1sınırlar ve beklenen ömürlerinde kısalma meydana gelir. Bu olumsuz durumu önlemek için standartlar eviricinin şebekeye verdiği d.a. akım değeri için sınırlama getirmiştir. d.a. akım sınır değeri IEEE 1547 standardında anma akımının \%0.5'i, IEC 61727 standardında \%1'i dir [7]. 


\section{FV-DÜB'lerin bulunduğu sistemlerde güç kalitesi problemlerinin iyileştirilmesi}

$\mathrm{Bu}$ bölümde, FV-DÜB'lerin bulunduğu sistemlerde gerilim dalgalanması, gerilim yükselmesi, gerilim dengesizliği ve harmonik bozulma problemlerinin iyileştirilmesinde kullanılan yöntemler sunulacaktır.

\subsection{Batarya enerji depolama sistemleri}

FV sistemlerde bataryalar enerji depolama birimi olarak tercih edilmektedir. Batarya enerji depolama elemanları üç çalışma durumuna sahiptir. Bu çalışma durumlarından biri olan yük dengeleme modunda, şebekedeki arzın talebi aştığı zamanlarda tüketilemeyen fazla enerji, talebin arzdan büyük olduğu durumlarda harcanmak üzere batarya bankalarında depolanır. Diğer çalışma durumu olan sınırlama modunda ise, FV paneller tarafindan üretilen ihtiyaç fazlası enerji bataryalarda depolanır ve böylece FVDÜB'lerin talep edilen gücün üzerinde bir güç değerini şebekeye vermesine bağlı gerilim yükselmesi probleminin meydana gelmesi önlenmiş olur. Arbitraj modunda ise enerjinin düşük fiyatlı olduğu durumlarda şebekeden enerji depolanır ve bu depolanan enerji fiyatın yükseldiği durumlarda kullanılır [21].

\subsection{Pasif ve aktif filtreler}

Pasif filtreler bobin, kondansatör ve direnç elemanlarından oluşan belli bir frekans veya frekans aralığına giren harmonik akımlarını süzen devrelerdir. Seri veya paralel tipleri mevcuttur. Seri tipleri evirici ile şebeke bağlantı noktası arasına bağlı olup süzülmek istenen harmoniklere yüksek empedans gösterecek şekilde tasarlanırlar ve bu harmonik akımlarını tıkarlar. Paralel pasif filtreler ise şebeke bağlantı noktası ile toprak arasına bağlanırlar ve süzülmek istenen harmoniklere düşük empedans gösterirler. Böylece bu harmonik akımları şebeke tarafına akmak yerine filtre üzerinden toprağa akarlar. Paralel pasif filtreler harmonik süzme özelliklerinin yanı sıra reaktif güç kompanzasyonu yetenekleri de olduğu için pratikte daha fazla tercih edilmektedir. Paralel pasif filtrelerin tek-ayarlı, çift-ayarlı, üç-ayarlı, C-tipi ve yüksek geçiren olmak üzere çeşitli tipleri vardır [36]. Şekil 10 (a)'da tek-ayarlı paralel pasif filtrenin bir faz eşdeğer devresi ve Şekil 10 (b)'de bu filtrenin empedans- harmonik numarası karakteristiği görülmektedir. $\mathrm{Bu}$ karakteristik eğrisinde $h_{\mathrm{t}}$ filtrenin ayarlandığ 1 harmonik numarasıdır.

Referans [35] çalışmasında, FV-DÜB'lerin bulunduğu güç sistemlerinde kompanzasyon kapasitörlerinin rezonansa yol açabileceği ve harmonik filtreler kullanılarak bu rezonans durumlarının önlenmesinin yanı sira uluslararası standartlarda tanımlı harmonik sınırlarını aşmadan sisteme bağlanacak azami FV-DÜB gücünün (sistemin FV-DÜB barındırma kapasitesinin) arttırılabileceği ifade edilmiştir. Bu çalışmaya paralel olarak, evirici ara yüzlü DÜB'ler için sistemin harmonik kısıtlara bağlı barındırma kapasitesinin iyileştirilmesinde pasif filtre kullanımı [37]'de tavsiye edilmiştir. Böylece, [38] ve [39] çalışmalarında, FV-DÜB'lerin harmonik sınırlamalara takılmadan şebekeye azami katılımı için optimal paralel pasif filtre tasarımları sunulmuştur. Bu çalışmalarda, standartlarda belirtilen harmonik sınırlamaların yanı sıra bağlantı noktası gerilim seviyesi ve güç faktörüne ilişkin sınırlamalarda dikkate alınmıştır. 


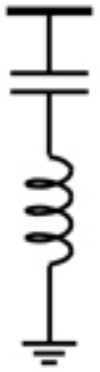

(a)

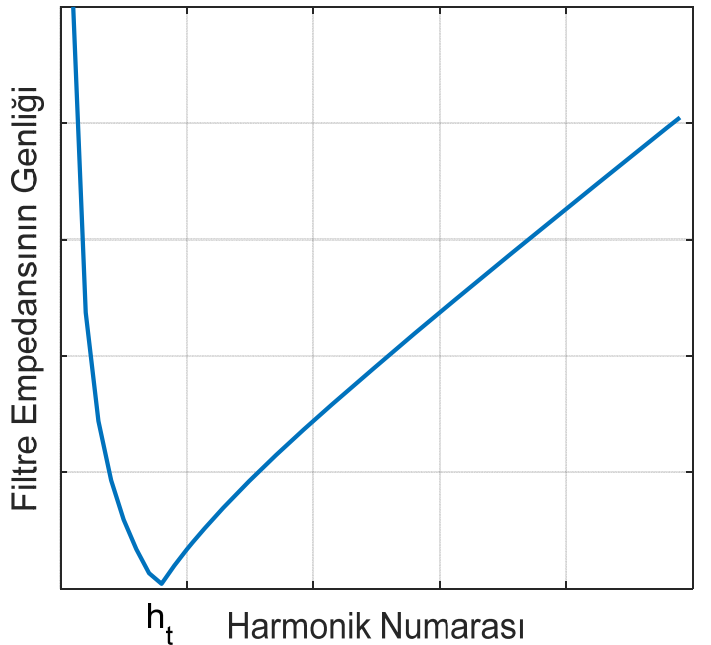

(b)

Şekil 10. Tek-ayarlı paralel pasif filtrenin (a) tek-faz eşdeğer devresi ve (b) empedansharmonik numarası karakteristiği.

Aktif filtreler, sisteme bağlanma şekline göre seri ve paralel olmak üzere iki tipe sahiptir. Bununla birlikte, pasif filtrelerde olduğu gibi aktif filtrelerinde paralel tipi seri tipine göre; reaktif güç kompanzasyonuna imkan tanıma avantajı sebebiyle daha fazla tercih edilmektedir. Paralel aktif filtreler, tüketiciye paralel olarak sisteme bağlanan ve harmonik akım kaynağı şeklinde kontrol edilen güç elektroniği devreleridir. Paralel aktif filtrelerin şebekeye enjekte edeceği akım dalga şekli; uygulnan anlık güç kompanzasyon stratejisine göre değişkenlik gösterir. Sinüzoidal-dengeli akım stratejisinde, aktif güç filtresi yük akımının temel frekans pozitif sıra aktif bileşeni dışındaki kısmını kompanze edecek şekilde sisteme akım enjekte eder [40]. Şekil 11'de sinüzoidal-dengeli akım stratejisine göre çalışan bir paralel aktif filtrenin bağlantı noktasına enjekte ettiği akım ( $\left.\mathrm{I}_{\mathrm{f}}\right)$ neticesinde; bozulmuş yük akımının ( $\left.\mathrm{I}_{\mathrm{y}}\right)$ filtrelenerek hat akımının $\left(\mathrm{I}_{\mathrm{k}}\right)$ saf sinüzoidal dalga formuna sahip olması görülmektedir.

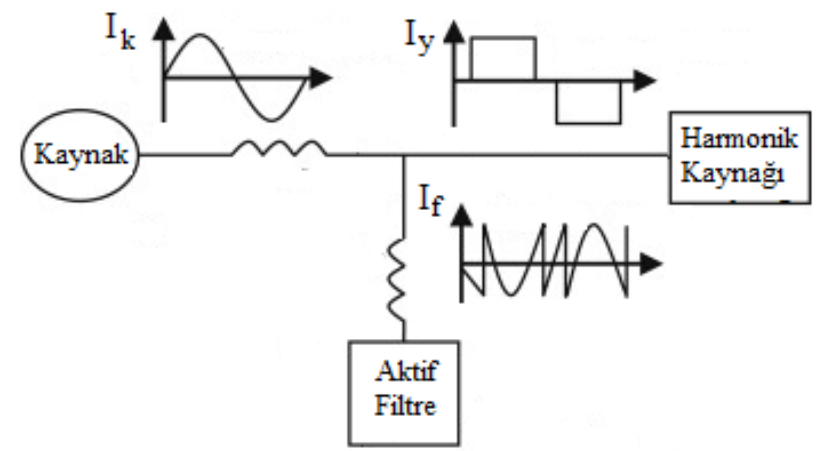

Şekil 11. Paralel aktif filtrenin sisteme bağlantısı ve çalışma prensibi.

FV-DÜB'lerin bulunduğu sistemlerde harmonik bozulma seviyelerinin iyileştirilmesi için literatürde pasif filtrelerin yanı sıra aktif filtreler de kullanılmıştır [41]. Ancak, özellikle son yıllarda yapılan çalışmalarda, ekstra bir aktif filtre kullanımı yerine, FVDÜB'lerin eviricilerine, kontrol algoritmalarında yapılan düzenlemelerle aktif filtre yeteneği kazandırılması amaçlanmıştır. Böylece, bu aktif filtre yeteneği kazandırılmış eviriciler, güç üretmenin yanı sıra şebeke bağlantı noktasındaki akımların harmonik 
bozulma, dengesizlik ve reaktif bileşenlerini kompanze etme özelliklerine sahip olmuştur [42-44].

\subsection{Esnek alternatif akım iletim sistemleri}

Esnek alternatif akım iletim sistemleri (FACTS) tristör anahtarlamalı ve eviricili sistemler olmak üzere iki ana başlık altında toplanabilir. Bu sistemler kullanılarak, mekanik anahtarlamalı kompanzatörlere göre reaktif gücün dolayısıyla sistem gerilim seviyesinin daha hızlı ve yumuşak kontrolü mümkündür [45]. Ulaşılabilen literatürden, statik var kompanzatör (SVC), dinamik gerilim düzenleyici (DVR), dağıtım tipi statik kompenzatör (D-STATCOM) ve birleşik güç akış kontrolörü (UPQC) olarak isimlendirilen çeşitli FACTS elemanlarının, FV-DÜB'lerin bulunduğu sistemlerde gerilim profilinin iyileştirilmesi için kullanımı üzerine çalışmalara ulaşılmıştır [46-54]. Bu FACTS elemanlarının şematikleri Şekil 12'de sunulmuştur.

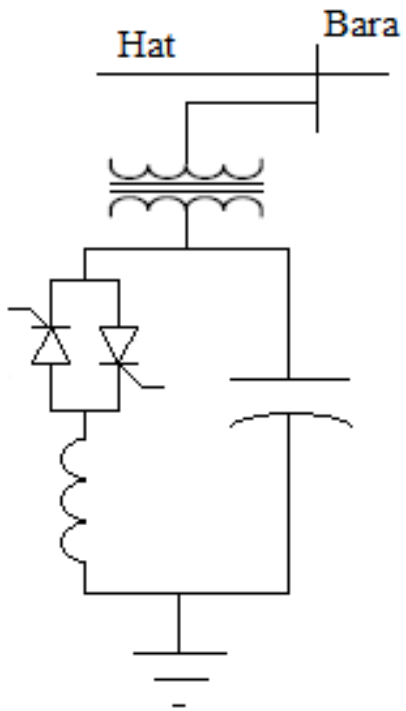

(a)

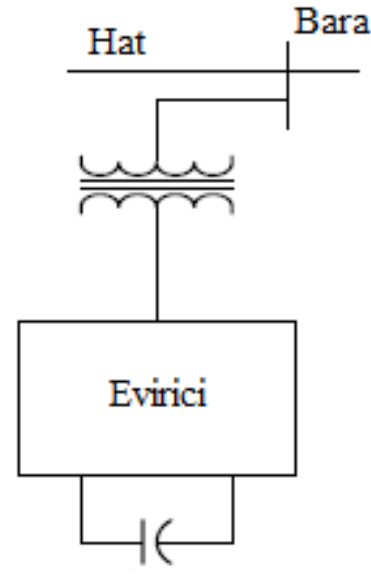

(c)

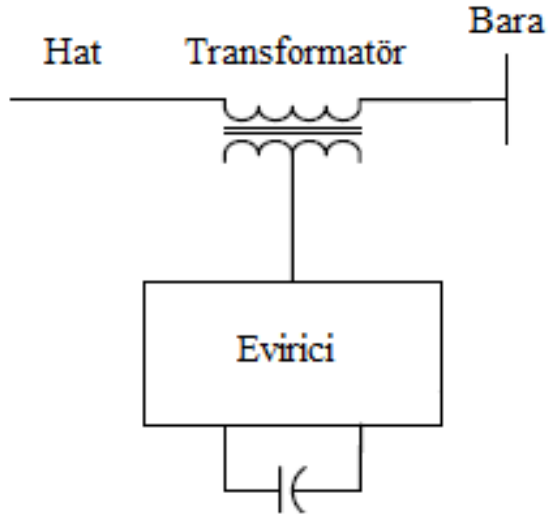

(b)

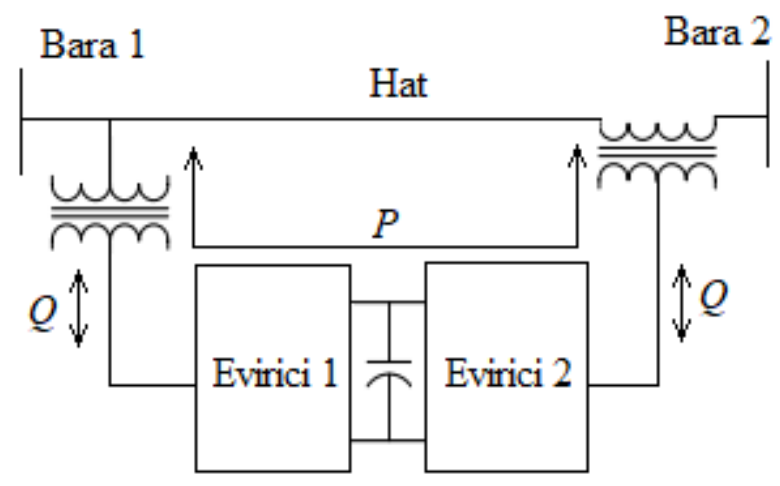

(d)

Şekil 12. (a) SVC, (b) DVR, (c) D-STATCOM ve (d) UPQC elemanlarının yapıları.

Şekil 12 (a)'dan SVC'nin paralel bağlı tristör kontrollü reaktör-kondansatör çifti ile şebekeye bağlantı transformatöründen, Şekil 12 (b) ve (c)'den DVR ve D- 
STATCOM'un kondansatör, evirici ve bağlantı transformatöründen, Şekil 12 (d)'den UPQC'nin DVR ve D-STATCOM'un birleşiminden oluştuğu görülmektedir [56].

SVC elemanı şebekeye paralel bağlanır ve yapısındaki tristörün tetikleme açıları ayarlanarak ihtiyaç duyulan kapasitif veya endüktif akımın sisteme enjekte edilmesine, böylece gerilimin belirlenen sınırlarda kontrolüne imkan verir. DVR elemanı hatta seri bağlanır ve çalışma prensibi evirici çıkış geriliminin ayarlanması ile hatta seri bağlı transformatörün sekonder tarafındaki bara gerilim profilinin düzenlenmesidir. Bara geriliminin indirilmesi veya yükseltilmesi ihtiyacına göre; DVR sırasıyla indüktif veya kapasitif bir elemanmış gibi davranır. D-STATCOM hatta paralel bağlanır. Bu eleman yapısındaki eviricinin çıkış geriliminin etkin değeri bara gerilimi etkin değerinden büyük ise; eviriciden hatta reaktif akım veya reaktif güç enjekte eder. Evirici çıkış gerilimi etkin değeri, bara gerilimi etkin değerinden küçük olduğu durumda ise; hattan eviriciye doğru reaktif akım akar ve D-STATCOM reaktif güç tüketir.

Referans [46]'da FV-DÜB'ler sebebiyle meydana gelen gerilim yükselmelerinin bastırılması için SVC kullanılmıştır. Aynı çalışmada sunulan analizler; SVC'nin dağıtım transformatörünün alçak gerilim tarafına yerleştirildiği durumda gereken anma gücünün, dağıtım transformatörünün yüksek gerilim tarafına yerleştirildiği durumdaki gerekli anma gücüne göre kayda değer derecede daha küçük olduğunu göstermiştir. [47]'de ise FV-DÜB'lerin ve rüzgar türbinlerinin bulunduğu sistemlerde gerilim profilini iyileştirmek için SVC'lerin optimal boyutlandırma ve yerleştirme problemi, NSGA-II isimli genetik algoritma kullanılarak çözülmüştür. Referans [48]'de çatı tipi tek fazlı FV-DÜB'lerin fazlara eşit güçte paylaştırılmadığı dağıtım sistemlerinde, gerilim profilinin ve dengesizliğinin iyileştirilmesi için DVR elemanı kullanılmıştır. Aynı çalışmada, ayrıca gerilim dengesizliği azaltma yetenekleri bakımından DVR ve DSTATCOM karşılaştırılmış ve bu analizlerde D-STATCOM'un daha iyi performans gösterdiği görülmüştür. Bununla birlikte hedeflenen iş için DVR'ın daha düşük anma değerlerine ihtiyaç duyduğu sonucuna varılmıştır. Referans [49]'da Güneş 1şınımının çok yüksek olduğu zamanlarda D-STATCOM'ların sistem geriliminin kontrolü için kullanılarak, dağıtım sisteminin FV-DÜB barındırma kapasitesinin iyileştirilmesi amaçlanmıştır. Analiz sonuçları D-STATCOM kullanımının FV-DÜB barındırma kapasitesini önemli derecede arttırdığını göstermiştir. Başka bir çalışmada [50], d.a. barası kapasite değeri küçültülmüş D-STATCOM'ların alçak gerilim dağıtım sistemlerinde FV-DÜB'lerin sisteme nüfuz etme sınırlarını iyileştirmek için kullanımı çalışılmıştır. Referans [51]'de d.a. barası kapasite değeri küçültülmüş UPFC'lerin, FVDÜB'lerin yüksek seviyede nüfuz ettiği alçak gerilim dağıtım sistemlerinde gerilim ayarlama ve gerilim dengesizlik problemlerinin çözümünde kullanımı çalışılmıştır. Buraya kadar bahsedilen çalışmaların yanı sıra literatürdeki bazı çalışmalarda [52-55], FV-DÜB'ler DVR, D-STATCOM/STATCOM veya UPFC görevi görecek biçimde tasarlanmiştır.

\section{Sonuçlar ve tartışma}

$\mathrm{Bu}$ derleme çalışmasında, öncelikle fotovoltaik dağıtık üretim birimlerinde (FV-DÜB) günümüzde gelinen teknolojik durum sunulduktan sonra FV-DÜB'lerin sebep olduğu güç kalitesi problemleri incelenmiştir.

İnceleme çalışması sonucunda, FV-DÜB'lerin, (i) Güneş enerjisinin emre amade olmaması sebebiyle gerilim dalgalanması ve gerilim yükselmesi problemlerine, 
(ii) yapılarında evirici var olması sebebiyle harmonik bozulma ve d.a. kirliliği problemlerine, (iii) tek fazlı evsel tiplerinin fazlara eşit dağıtılmaması sebebiyle gerilim dengesizliği problemine yol açtığı görülmüştür. $\mathrm{Bu}$ güç kalitesi problemlerinin sınırlandırılması için oluşturulan birçok uluslararası standart olduğu ancak bu standartlardan önde gelenlerinin IEEE 1547, IEEE 929 ve IEC 61727 olduğu tespit edilmiştir.

Son olarak, FV-DÜB'lerin bulunduğu sistemlerde gerilim dalgalanması, gerilim yükselmesi, gerilim dengesizliği ve harmonik bozulma problemlerinin iyileştirilmesinde, batarya enerji depolama sistemleri, pasif/aktif güç filtrelerin ve esnek alternatif akım iletim sistemlerinin (SVC, DVR, D-STATCOM ve UPQC) kullanıldığ görülmüştür. Ayrıca, literatürdeki bazı çalışmalarda FV-DÜB'lere, aktif filtre, DVR, DSTATCOM ve UPQC olarak çalışma yeteneklerinin kazandırılmasına ilişkin tasarımların yapıldığı görülmüştür.

\section{Teşekkür}

Bu çalışma, 116E110 nolu TÜBİTAK 1001 projesi kapsamında desteklenmiştir.

\section{Kaynaklar}

[1] Ackermann, T., Anderson, G. ve Söder, L., Distributed generation: a definition, Electr. Power Syst. Res., 57, 195-204, (2001).

[2] Paliwal, P., Patidar, N.P. ve Nema, R.K., Planning of grid integrated distributed generators: a review of technology, objectives and techniques, Renew. Sustain. Energy Rev., 40, 557-570, (2014).

[3] Li, L., Mu, H., Li, N. ve Li, M., Economical and environmental optimization for distributed energy resource system coupled with district energy networks, Energy, 109, 947-960, (2016).

[4] Katiraei, F. ve Aguero, J.R., Solar PV integration challenges, IEEE Power and Energy Mag., 9, 62-71, (2011).

[5] Jager-Waldau A., PV Status Report 2018, European Union, Brussels, (2018).

[6] Masson G., Orlandi S. ve Rekinger M., Global market outlook for photovoltaics: 2014-2018, Brussels, Belgium, European Photovoltaic Industry Association, (2013).

[7] Wu Y.K., Lin J.H. ve Lin H.J., Standards and guidelines for grid-connected photovoltaic generation systems: a review and comparison, IEEE Trans. Ind. Appl., 53, 3205-3216, (2017).

[8] Mohsen M., Hwai Chyuan O., Chong, W.O. ve Leong, K.Y., Advances and challenges in grid tied photovoltaic systems, Renew. Sustain. Energy Rev., Volume 49, 121-131, (2015).

[9] Hassaine, L., OLias, E., Quintero, J. ve Salas, V., Overview of power inverter topologies and control structures for grid connected photovoltaic systems, Renew. Sustain. Energy Rev., 30, 796-807, (2014).

[10] Kouro, S., Leon, J.I., Vinnikov D. ve Franquelo, L.G., Grid-connected photovoltaic systems: an overview of recent research and emerging PV converter technology, IEEE Ind. Electron. Mag., 9, 47-61, (2015). 
[11] Manasseh, O. ve Robert, B., Trends and challenges of grid-connected photovoltaic systems, Renew. Sustain. Energy Rev., 58, 1082-1094, (2016).

[12] Anzalchi, A. ve Sarwat, A., Overview of technical specifications for gridconnected photovoltaic systems, Energ. Convers. Manage., 152, 312-327, (2017).

[13] Chin, V.J., Salam, Z. ve Ishaque, K., Cell modelling and model parameters estimation techniques for photovoltaic simulator application, Appl. Energy, 154, 500-519, (2015).

[14] Bhatnagar, P. ve Nema, R.K., Maximum power point tracking control techniques: State-of-the-art in photovoltaic applications, Renew. Sustain. Energy Rev., 23, 224-241, (2013).

[15] Bendib, B., Belmili, H. ve Krim, F., A survey of the most used MPPT methods: Conventional and advanced algorithms applied for photovoltaic systems, Renew. Sustain. Energy Rev., 45, 637-648, (2015).

[16] IEEE Std 1547-2003, IEEE standard for interconnecting distributed resources with electric power systems, IEEE Standard, USA, (2003).

[17] IEEE Std 1547a-2014, IEEE standard for interconnecting distributed resources with electric power systems-amendment 1, IEEE Standard, USA, 2014.

[18] IEC 61727-2004, Photovoltaic (PV) systems-characteristics of the utility interface, IEC standard, Switzerland, (2004).

[19] IEEE Std 929-2000, IEEE recommended practice for utility interface of photovoltaic (PV) systems, IEEE Standard, USA, (2000).

[20] Karimi, M., Mokhlis, H., Naidu, K., Uddin, S. ve Bakar, A.H.A., Photovoltaic penetration issues and impacts in distribution network - a review, Renew. Sustain. Energy Rev., 53, 594-605, (2016).

[21] Mejbaul Haque, M. ve Wolfs, P., A review of high PV penetrations in LV distribution networks: Present status, impacts and mitigation measures, Renew. Sustain. Energy Rev., 62, 1195-1208, (2016).

[22] Von Jouanne A. ve Banerjee B., Assessment of voltage unbalance, IEEE Trans. Power Del., 16, 782-790, (2011).

[23] Kurt, M.S., Balci, M.E. ve Abdel Aleem, S.H.E., Algorithm for estimating derating of induction motors supplied with under/over unbalanced voltages using response surface methodology, The JoE, 12, 627-633, (2017).

[24] Rodriguez-Calvo, A., Cossent, R. ve Frías, P., Integration of PV and EVs in unbalanced residential LV networks and implications for the smart grid and advanced metering infrastructure deployment, Int. J. Elec. Power, 91, 121-134, (2017).

[25] Shou T., Wang H., Zhu T., Zhu L., Wang Q. ve Lou X., Harmonic current suppression for three phase PV generation system under unbalanced grid voltage. APPEEC 2013, 1-6, Kowloon, China, (2013).

[26] Huang H., Xu Y. ve Yang L., Control scheme of PV inverter under unbalanced grid voltage, 2014 IEEE PES General Meeting, 1-5, National Harbor, USA, (2014).

[27] Singh, G.K., Power system harmonics research: a survey, Eur. Trans. Electr. Power, 19, 151-172, (2009).

[28] Kalair, A., Abas, N., Kalair, A.R., Saleem, Z. ve Khan, N., Review of harmonic analysis, modeling and mitigation techniques, Renew. Sustain. Energy Rev., 78, 1152-1187, (2017). 
[29] Gianfranco C., Jürgen S. ve Filippo S., Experimental assessment of the waveform distortion in grid-connected photovoltaic installations, Sol. Energy, 83, 1026-1039, (2009).

[30] Yang D., Dylan Dah-Chuan L., Geoffrey J. ve Cornforth, D.J., Modeling and analysis of current harmonic distortion from grid connected PV inverters under different operating conditions, Sol. Energy, 94, 182-194, (2013).

[31] Taylor, T., Gonzalez, O. ve Baghzouz, Y., Analysis of current distortion in a 12 $\mathrm{kW}$ photovoltaic system installation, 17th ICHQP, 243-248, Belo Horizonte, Brazil, (2016).

[32] IEEE std. 519-2014, IEEE recommended practices and requirements for harmonic control in electrical power systems, IEEE standard, USA, (2014).

[33] Bhowmik, A., Maitra, A., Halpin, S.M. ve Schatz, J.E., Determination of allowable penetration levels of distributed generation resources based on harmonic limit considerations, IEEE Trans. Power Del., 18, 619-24, (2013).

[34] Ravikumar, P., Zeineldin, H.H. ve Xiao, W., Allowable DG penetration level considering harmonic distortions, IECON Proc. Industrial Electron, 814-818, Melbourne, Australya, (2011).

[35] Dartawan, K., Hui L. ve Pterra, M., Harmonics issues that limit solar photovoltaic generation on distribution circuits, WREF 2012, 1-7, Denver, USA, (2012).

[36] Das, J. C., Power system harmonics and passive filter designs, Wiley-IEEE Press, New Jersey, USA, (2015).

[37] Harrison, G.P. ve Djokic, S.Z., Distribution network capacity assessment: incorporating harmonic distortion limits, IEEE power \& energy society general meeting, 1-7, San Diego, USA, (2012).

[38] Sakar, S., Balci, M. E., Abdel, Aleem, S. H. E. ve Zobaa, A. F., Increasing PV hosting capacity in distorted distribution systems using passive harmonic filtering, Electr. Power Syst. Res., 148, 74-86, (2017).

[39] Sakar, S., Balci, M.E., Abdel Aleem, S.H.E ve Zobaa, A.F., Integration of largescale PV plants in non-sinusoidal environments: Considerations on hosting capacity and harmonic distortion limits, Renew. Sustain. Energy Rev., 82, 176186, (2018).

[40] Akagi, H., Watanebe, E. H. ve Aredes, M., Instantaneous power theory and applications to power conditioning, Wiley-IEEE Press, New Jersey, USA, (2017).

[41] Huda, A. S. N. ve Živanović, R., Large-scale integration of distributed generation into distribution networks: Study objectives, review of models and computational tools, Renew. Sustain. Energy Rev., 76, 974-988, (2017).

[42] Tsengenes, G. ve Adamidis, G., A multi-function grid connected PV system with three level NPC inverter and voltage oriented control, Sol. Energy, 85, 2595-2610, (2016).

[43] Noroozian, R. ve Gharehpetian, G.B., An investigation on combined operation of active power filter with photovoltaic arrays, Int. J. Elec. Power, 46, 392-399, (2013).

[44] Zeng, Z., Yang, H., Zhao, R. ve Cheng, C., Topologies and control strategies of multi-functional grid-connected inverters for power quality enhancement: a comprehensive review, Renew. Sustain. Energy Rev., 24, 223-270, (2013).

[45] Gelen, A. ve Yalçınöz, T., Tristör anahtarlamalı kapasitör (TSC) ve tristör anahtarlamalı reaktör-tabanlı atatik VAr kompanzatör'ün (TSR-Tabanlı SVC) PI ile kontrolü, Gazi Üniv. Müh. Mim. Fak. Der., 24, 237-244, (2009). 
[46] Iioka, D., Sakakibara, K., Yokomizu, Y., Matsumura, T. ve Izuhara, N., Distribution voltage rise at dense photovoltaic generation area and its suppression by SVC, Electr. Eng. Jpn., 166, 47-53, (2009).

[47] Durisic, A.S.Z., Optimal sizing and location of SVC devices for improvement of voltage profile in distribution network with dispersed photovoltaic and wind power plants, Appl. Energy, 134, 114-124, (2014).

[48] Shahnia, F., Ghosh, A., Ledwich, G. ve Zare, F., Voltage unbalance improvement in low voltage residential feeders with rooftop PVs using custom power devices, Int. J. Elec. Power, 55, 362-377, (2014).

[49] Chao-Shun, C., Chia-Hung, L., Wei-Lin, H., Cheng-Ting, H. ve Te-Tien, K., Enhancement of PV penetration with DSTATCOM in Tai power distribution system, IEEE Trans. Power Syst., 28, 1560-1567, (2013).

[50] Wolfs, P., Improvements to LV distribution system PV penetration limits using a DSTATCOM with reduced DC bus capacitance, 2013 IEEE PES Meeting, 1-5, Vancouver, Canada, (2013).

[51] Wolfs, P. A., UPFC with reduced DC bus capacitance for LV distribution netWorks with high PV penetrations, 22nd AUPEC, 1-7, Bali, Indonesia, (2012).

[52] Ramasamy, M. ve Thangavel, S., Experimental verification of pv based dynamic voltage restorer (PV-DVR) with significant energy conservation, Int. J. Elec. Power, 49, 296-307, (2013).

[53] Rajiv, K., Varma, V.K., ve Ravi, S., Nightime application of PV solar farm as STATCOM to regulate grid voltage, IEEE Trans. Energy Convers., 24, 983985, (2009).

[54] Yahia, B., Kurt, E., Chenni, R. ve Altın, N., Design and simulation of a unified power quality conditioner fed by solar energy, Int. J. Hydrogen Energy, 40, 15267-15277, (2015).

[55] Sezen, S., Aktas, A., Ucar, M., Ozdemir, E., Design and operation of a multifunction photovoltaic power system with shunt active filtering using a single-stage three-phase multilevel inverter, Turk. J. Elec. Eng. \& Comp. Sci., 25, 1412-1425, (2017).

[56] Padiyar, K. R., FACTS: Controllers in power transmission and distribution, Anshan Publishers, 2009. 